I would like to emphasize a number of points:

Programmes of this kind take a long time to plan and develop. Forward thinking is essential; success depends on stability, consistent policy, and, where necessary, the patient persistence that we mentioned earlier.

We cannot, of course, carry out the basic review of world problems all at once. It is necessary to examine the regions and problems one by one in a planned sequence; and this is what we are doing. The process could be speeded up, but only if our resources were increased accordingly. I must also emphasize that a world strategy and action plan can never be complete and final. It must be continuously reviewed and revised. Some problems will, we hope, be solved; but more frequently as one kind of action is completed, other priorities will emerge. We should look upon the world conservation strategy, therefore, as a kind of register-which must be continually kept up to date-of priorities for action, backed by notes on practicability, the most effective approach, who might carry out the action, and how. But although priorities must change from time to time, fundamental changes of direction would destroy any impetus we may have gained.

After deciding on the most desirable and practicable strategy, the next and most important stage is, of course, to try and ensure that the action takes place. Here IUCN is developing a network of consultative mechanisms of which some are of particular importance. Thus the Ecosystem Conservation Group (UNEP, FAO, UNESCO, and IUCN) is being strengthened to ensure that action takes place within the broad strategies developed by UNEP; for this the work of FAO, UNESCO, and IUCN, should develop in concord and, we hope, along the lines which we have identified. The strategies developed by IUCN should form the blue-print for action in the conservation and management of ecosystems and in the conservation of species.

The close accord developed with WWF should ensure that WWF can support a well-integrated conservation programme which should appeal to those who provide money to it and will ensure that the funds available to WWF for international conservation are spent to the very best advantage. Another powerful spearhead for action should be the members of IUCN themselves. One of our must significant tasks must be to mobilize the full capacity of the members of IUCN, both governmental and non-governmental, to carry forward the strategy which we design.

Conservation is a unitary process. It depends equally on good science, a public that is educated and aware, good laws, good planning, and good administration. The aims and purposes of all the IUCN Commissions converge. For this reason I am proposing to all of them that they should devote much thought in the coming months to their role in relation to one another and to the programme as a whole, and that a meeting of all Commission Chairmen and ViceChairmen should be called in late 1977 or early 1978 to plan for the next decade.

One crucial problem is final implementation. We are identifying many more problems than there are international resources to implement. WWF does much, but funds within each country, international funds, and bilateral aid funds, will be needed on a much larger scale if our efforts are to bear fruit.

I would like to add something on a personal note. In this programme we have now begun to build a solid foundation for future action-without a solid foundation it is vain to try to build a solid structure. But what we have done is only a beginning. The Union is concerned with values more, I would say, even than with science. For science should be the servant and not the master of mankind. Our programme must be firmly based in realism, but it must move ahead with vision. We should be the architects of guided change (call it development if you will)-guided in the direction of the 'good life' as well as the material well-being of Man, but (and the 'but' is all-important) in such a way that the potential of the biosphere to support this good life is not diminished. In particular we need to pay much more attention to the ways in which conservation can become part of development plans founded on local social and economic realities.

This is the way IUCN should go, and is the way in which, with care and wisdom in the development of our programme, I firmly believe it can and will go.

DuNCAN PoORE, Acting Director-General
I.U.C.N.
I110 Morges
Switzerland.
I.U.C.N. Switzerland.

\title{
Efforts Renewed to Improve Control of Trade in Endangered Species
}

The World Wildlife Fund is making a new drive to get governments which have not so far acceded to the Convention un International Trade in Endangered Species of Wild f auna and Flora to do so as soon as possible.

So far 35 countries are parties to the Convention, which can $: \geqslant$ into force on 1 July 1975. They are Australia, Brazil, Cansda, Chile, Costa Rica, Cyprus, Ecuador, Finland, East Germany, West Germany, Ghana, India, Iran, Madagascar, Mauritius, Morocco, Nepal, Niger, Nigeria, Norway, Pakistan, Papua New Guinea, Paraguay, Peru, Seychelles, South Africa, Sweden, Switzerland, Tunisia, Union of Soviet Socialist Republics, United Arab Emirates, the United Kingdom, United States of America, Uruguay, and Zaïre.

Although representations have been made before, the World Wildlife Fund is now making renewed efforts to broaden international acceptance of the Convention, which is zonsidered one of the key methods of stopping the dangercus drain on threatened plants and animals through comimercial activities-quite apart from excessive hunting, collection, and the effects of pollution and other results of human population-pressures. Countries are being asked to accede as soon as possible, and meanwhile to act in the spirit of the Convention.

The Convention attempts to control the situation by imposing a virtual ban on trade in the most endangered species, including Tiger, Asiatic Lion, Leopard, Snow Leopard, Gorilla, Orang-utan, rhinoceroses, Asiatic Elephant, White-tailed, Bald and Imperial Eagles, Peregrine Falcon, crocodiles, and most orchids. In addition, approved export and import permits are required for all international movements of these species or parts of them.

A second list covers species which could become endangered unless trade is carefully monitored. This list includes all cats, otters, monkeys, and eagles not in the first list, African Elephant, all fur seals, Red-breasted Goose, Great Indian Hornbill, and a number of birdwing butterflies. Approved export permits are required which ensure close watching of the trade.

A third list contains species which countries protect locally and for which they need the cooperation of other governments to reinforce their domestic legislation.

It is considered of crucial importance for all members of the European Economic Community and Japan to accept the Convention because they are major importers. Among the nine nations of the European Economic Community (EEC), only Britain and West Germany have so far become parties.

PETER F. R. JACKSON, Director of Information World Wildlife Fund 1110 Morges Switzerland. 